\title{
Questions and Answers for Using Sunn Hemp (Crotalaria juncea L.) as a Green Manure Cover Crop ${ }^{1}$
}

\author{
Thioro Fall, Ariel Freidenreich, Stacy Swartz, Christopher Vincent, Yuncong Li, and Zachary \\ Brym $^{2}$
}

This document synthesizes information about the warmseason cover crop, sunn hemp. It addresses frequently asked questions for growers and summarizes the expanding body of sunn hemp research. The information is provided so growers in Florida can learn about up-to-date cultivation and management options as well as better understand sunn hemp's practical uses. This document is a follow-up to EDIS documents SL 306 (https://edis.ifas.ufl.edu/tr003) and ENY-717 (https://edis.ifas.ufl.edu/ng043).

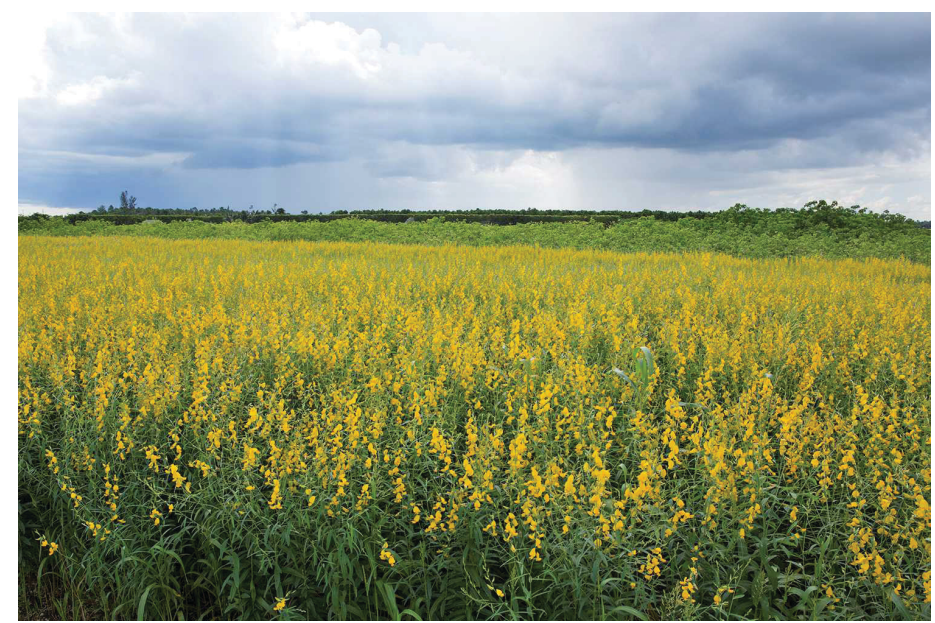

Figure 1. Sunn hemp flowering during the summer growing season in southern Florida.

Credits: Tyler Jones, UF/IFAS Communications

\section{What is the origin of sunn hemp?}

Sunn hemp is from India, where it is grown for fiber, forage, and as a cover crop. It is grown in the United States for the same purposes.

\section{Why grow sunn hemp as a cover crop?}

Sunn hemp is used to increase rotational crop yields and reduce invertebrate pest pressure. Sunn hemp residue adds nutrients and organic matter to the soil and may enhance soil microbiota. Most studies of vegetables planted after sunn hemp have found increased vegetable yields. Sunn hemp also suppresses weeds and nematodes. Its residue contains plant defense compounds, called allelochemicals, that inhibit or delay germination of weed seeds and the life cycle of nematodes.

\section{What is the difference between sunn hemp (Crotalaria juncea) and hemp (Cannabis sativa)?}

Crotalaria juncea and Cannabis sativa are both plants historically cultivated for fiber production, which is why they are both called "hemp." However, sunn hemp (C. juncea) is a legume from India, while $C$. sativa is a non-legume from China. Sunn hemp does not produce cannabinoids while hemp does.

1. This document is SS-AGR-444, one of a series of the Agronomy Department, UF/IFAS Extension. Original publication date July 2020. Visit the EDIS website at https://edis.ifas.ufledu for the currently supported version of this publication.

2. Thioro Fall, Ph.D. student, UF/IFAS Tropical Research and Education Center; Ariel Freidenreich, Ph.D. candidate, graduate teaching assistant, Florida International University; Stacy Swartz, Master's student, ECHO Global Farm; Christopher Vincent, assistant professor, Horticultural Sciences Department, UF/IFAS Citrus Research and Education Center; Yuncong Li, professor, Department of Soil and Water Sciences, UF/IFAS TREC; and Zachary Brym, assistant professor, Agronomy Department, UF/IFAS TREC; UF/IFAS Extension, Gainesville, FL 32611.

The Institute of Food and Agricultural Sciences (IFAS) is an Equal Opportunity Institution authorized to provide research, educational information and other services

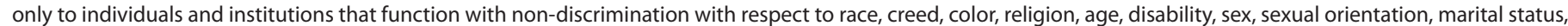

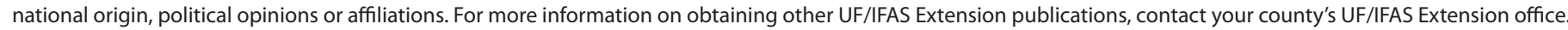
U.S. Department of Agriculture, UF/IFAS Extension Service, University of Florida, IFAS, Florida A \& M University Cooperative Extension Program, and Boards of County Commissioners Cooperating. Nick T. Place, dean for UF/IFAS Extension. 


\section{Which plant hardiness zones are suitable for growing sunn hemp?}

Although sunn hemp is of tropical origin, it has been cultivated in temperate zones as far north as Washington state. It is recommended for planting in the warm season in USDA plant hardiness zones 8-13. Southern varieties such as 'Tropic Sun' may be less tolerant to northern climates than northern varieties such as 'AU Golden' and 'Ubon'.

\section{Where can I get sunn hemp seeds?}

In south Florida, sunn hemp seeds are currently sold for about $\$ 1.50 / \mathrm{lb}$ and are available from many seed distributors. Contact your local seed vendors or UF/IFAS Extension office for options.

\section{What is the seeding rate for sunn hemp? How deep should I plant it? Do I need to add an inoculant when planting sunn hemp?}

Recommended seeding rates for Florida are 25-50 lb/acre. Sunn hemp should be planted at a depth of one inch or less in loose soil using a grain drill or a broadcast method. The broadcast method may require the higher end of the seeding rate because many seeds may not adequately penetrate to an appropriate depth. Although inoculation with Rhizobium bacteria is standard practice when seeding legumes, many growers in south Florida have reported acceptable biomass yield without inoculation. Inoculation with cowpea-type Rhizobium spp. is recommended for maximum nitrogen production.

\section{Do I have to fertilize and irrigate sunn hemp?}

Sunn hemp requires very little care and is fairly droughttolerant. It is best to plant when the soil is moist and warmer than $68^{\circ} \mathrm{F}$. Lack of water during the establishment phase can inhibit germination, plant density, and initial growth. If rainfall is insufficient, irrigating from seeding until two weeks after germination will aid in establishment. As a legume, sunn hemp forms symbiotic relationships with rhizobia in the soil, which fix atmospheric nitrogen into plant-available forms. This minimizes the nitrogen requirement for the crop. Fertilizer at a rate of $30 \mathrm{lb} /$ acre of N, $\mathrm{P}_{2} \mathrm{O}_{5}$, and $\mathrm{K}_{2} \mathrm{O}$ can be applied after germination to facilitate faster growth.

\section{Can I mix sunn hemp seeds with other cover crops?}

Sunn hemp is often mixed with sorghum sudangrass (Sorghum bicolor $\mathrm{x}$ S. bicolor var. sudanense). This cover crop combination results in several benefits. Sorghum sudangrass scavenges excess nitrogen from the soil to produce biomass with a high C: $\mathrm{N}$ ratio. The mixture of plants can increase overall biomass and diversity that benefits nutrient cycling and soil microorganisms. Sunn hemp can also be mixed with other legumes, such as American joint vetch (Aeschynomene americana), cowpea (Vigna unguiculata), hairy indigo (Indigofera hirsuta), and slender leaf rattlebox (Crotalaria ochroleuca). The smaller stature of northern varieties, such as 'AU Golden' and 'Ubon', may be beneficial for multispecies cover crop mixtures. Adjust seeding rates, starting with an even split of the rates (i.e., 50\%:50\%), to accommodate biomass accumulation.

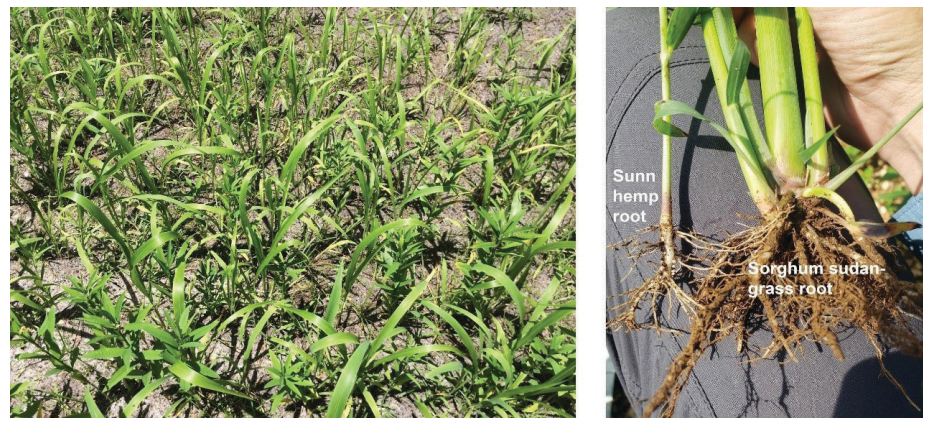

Figure 2. Sunn hemp and sorghum sudangrass grown in mixture at five weeks after planting (left) and mature sunn hemp and sorghum sudangrass roots (right).

Credits: Stacy Swartz and Daniel Calzadilla

\section{How many days should sunn hemp be grown as a cover crop?}

Sunn hemp should be mowed 60 to 90 days after planting. Many growers have reported mechanical difficulties when incorporating sunn hemp after 90 days due to excessive plant height and tough, fibrous stems. Another management strategy for sunn hemp involves early mowing or cutting the main stem using a hedge trimmer or loppers, which induces secondary branching.

\section{Can sunn hemp be mixed with tree crops?}

Sunn hemp can be intercropped with tree crops when grown in aisles, alleys, or row middles so that it has access to direct sunlight. It can be cut and spread as mulch within the tree rows. Sunn hemp has been used successfully as an intercrop in carambola, coffee, citrus, papaya, and pineapple systems.

\section{What are disease, insect, and wildlife problems associ- ated with sunn hemp?}

Sunn hemp does not have major disease and invertebrate pest problems in south Florida. However, there are reports of disease and insect occurrences for sunn hemp growing 
in other areas. If planted in waterlogged soils, sunn hemp is susceptible to root rots. Insect species in the order Lepidoptera (mainly moths and pod borers) may attack seedpods, stems, or leaves. Deer, hogs, and rabbits may browse in fields of sunn hemp, disrupting or destroying the crop.

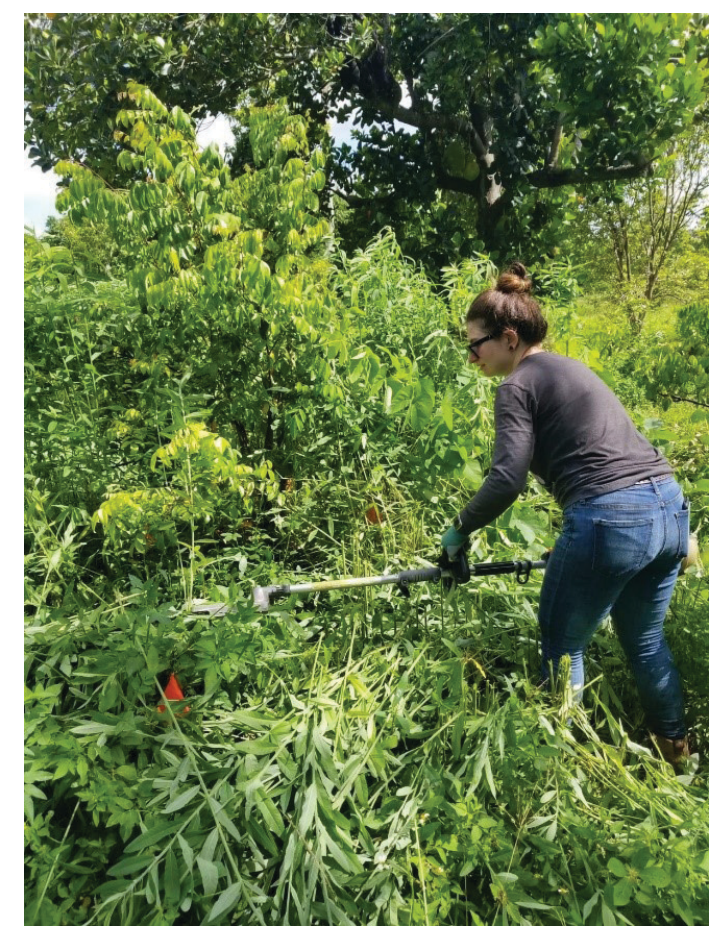

Figure 3. Sunn hemp grown with tropical fruit trees (carambola) being cut with a hedge trimmer.

Credits: Ariel Freidenreich

\section{Which kinds of machinery are needed to mow and incorporate sunn hemp into the soil?}

Sunn hemp can be mowed with a tractor-drawn rotary mower (a "bush hog") or silage chopper and incorporated with a disk plow. Alternatively, a roller-crimper can be used to break plant stems, terminate the crop, and provide a layer of mulch in the field. If grown with tree crops, sunn hemp can be terminated with a hedge trimmer and residues can be spread around tree bases.

\section{What is the maximum level of dry matter production by sunn hemp?}

Sunn hemp can produce up to 13 tons of dry biomass per acre, although 2-5 tons per acre may be more typical. Of course, dry matter production depends on environmental conditions and management practices. Sunn hemp can tolerate soils with poor fertility but will not produce the same quantity of biomass under these conditions as in more fertile soils. Sunn hemp is not adapted to poorly drained soils, so establishment and production will be significantly lower in those soils.

\section{How much nitrogen can sunn hemp accumulate? How much nitrogen is available for the following cash crop?}

The aboveground parts of sunn hemp can accumulate up to $300 \mathrm{lb}$ of nitrogen per acre, although planting date and location can affect nitrogen accumulation. The method used to mow and incorporate the crop can affect the decomposition rate and mineralization of nitrogen depending on how intact the crop biomass remains and whether it was left on the surface or buried. Although exact amounts of nitrogen available for subsequent crops vary widely depending on location and management factors, vegetable yields have been shown to respond favorably. Overall nitrogen leaching can be reduced when sunn hemp is incorporated into the soil by increasing soil organic matter. However, nitrogen leaching may also increase shortly after termination due to rapid decomposition of plant residue.

\section{Can I use sunn hemp as mulch?}

Sunn hemp has good potential as mulch when grown in proximity to its use location, such as between vegetable beds or fruit tree rows. Sunn hemp is best planted and mulched where suppression of weed seed germination is desired and small-seeded crops are not seeded with direct exposure to the sunn hemp residue.

\section{Can I use it as a windbreak?}

Sunn hemp can be used as windbreak for vegetable and small tree crops that are sensitive to wind damage. Sunn hemp greatly reduces wind speed and can be properly managed to minimize shading. It is recommended to mow or cut sunn hemp at 60-90 days, before it creates excessive shade. Sunn hemp windbreaks also interrupt the movement of vector pests, reducing the spread of disease.

\section{Will sunn hemp suppress nematodes?}

Sunn hemp can suppress plant-parasitic nematodes such as root-knot (Meloidogyne incognita) and reniform (Rotylenchulus reniformis) nematodes by producing allelochemicals that disrupt nematode life cycles. It is a non-host for nematodes and promotes the growth of antagonistic microorganisms and beneficial nematodes. Nematode pest populations can be reduced for several weeks after incorporation of sunn hemp into the soil. 


\section{Are there any disadvantages to using sunn hemp as a cover crop?}

Sunn hemp can become woody and challenging to terminate if grown for too long. A balance between biomass production and ease of field maintenance is important to consider when scheduling and timing sunn hemp management. Timing of subsequent direct-seeded crops is also important to consider in the use of sunn hemp as a cover crop due to allelochemical effects of residues on crop seeds. Sunn hemp is best in rotation with crops that tolerate allelochemicals, or when given sufficient time for residues to decompose before subsequent cropping.

\section{Can you use sunn hemp as an animal feed?}

Some varieties of sunn hemp produce harmful alkaloids (most highly concentrated in seeds), while others are nontoxic and make excellent forage. 'Tropic Sun' is a standard variety that is safe for animal feed. 'AU Golden' and 'AU Durbin' have high leaf quality for livestock feed (25-30\% crude protein). Because leaves have greater nutritive value than stems, seeding at lower densities encourages high leaf-to-stem ratios and increases the forage value. Begin grazing livestock on sunn hemp plants when the plants reach a height of 1.5-3 feet. This prevents plants from growing too tall for the livestock to reach. To allow regrowth, stubble should not be reduced by grazing to less than 12-18 inches tall. About $20 \%$ production from regrowth may be expected.

\section{What are other uses of sunn hemp?}

Although sunn hemp is grown in Brazil, India, and Pakistan as a source of fiber, the processing industries needed to produce fiber from the crop are not present in the United States. India is the largest producer of sunn hemp fiber for use in products such as twine, fishing nets, ropes, and floor mats. However, production of sunn hemp for fiber has declined in recent years due to competition from synthetic fiber production.

\section{References}

Abdul-Baki, A. A., H. H. Bryan, G. M. Zinati, W. Klassen, M. Codallo, and N. Heckert. 2001. "Biomass Yield and Flower Production in Sunn Hemp: Effect of Cutting the Main Stem." J. Veg. Crop Prod. 7: 83-104. https://doi. org/10.1300/J068v07n01_10
Adler, M. J., and C. A. Chase. 2007. "Comparison of the Allelopathic Potential of Leguminous Summer Cover Crops: Cowpea, Sunn Hemp, and Velvet Bean." HortScience 42(2): 289-293: https://doi.org/10.21273/HORTSCI.42.2.289

Baligar, V. C., and N. K. Fageria. 2007. "Agronomy and Physiology of Tropical Cover Crops." J. Plant Nutr. 30: 1287-1339: https://doi.org/10.1080/01904160701554997

Chase, C. A., and S. B. Coplin. 2017. "A Cover Crop Mixture for Weed and Sting Nematode Management." Weed Science Society of America Meeting Abstract 320.

Schomberg, H. H., N. L. Martini, J. C. Diaz-Perez, S. C. Phatak, K. S. Balkcom, and H. L. Bhardwaj. 2007. "Potential for Using Sunn Hemp as a Source of Biomass and Nitrogen for the Piedmont and Coastal Plain Regions of the Southeastern USA." Agron. J. 99: 1448-1457. https://doi. org/10.2134/agronj2006.0294

Skinner, E. M., J. C. Díaz-Pérez, S. C. Phatak, H. H. Schomberg, and W. Vencill. 2012. "Allelopathic Effects of Sunnhemp (Crotalaria juncea L.) on Germination of Vegetables and Weeds." HortScience 47(1): 138-142. https:// doi.org/10.21273/HORTSCI.47.1.138

Vincent, C., B. Schaffer, D. L. Rowland, K. W. Migliaccio, J. H. Crane, and Y. Li. 2017. "Sunn Hemp Intercrop and Mulch Increases Papaya Growth and Reduces Wind Speed and Virus Damage." Scientia Horticulturae 218: 304-315. https://doi.org/10.1016/j.scienta.2017.02.042

Wang, Q., W. Klassen, H. Bryan, Y. C. Li, and A. A. AbdulBaki. 2003. "Influence of Summer Cover Crops on Growth and Yield of a Subsequent Tomato Crop in South Florida." Proc. Fla. State Hortic. Soc. 116: 140-143.

Wang, Q. R., Y. C. Li, and W. Klassen. 2007. "Changes of Soil Microbial Biomass Carbon and Nitrogen with Cover Crops and Irrigation in a Tomato Field." J. Plant Nutr. 30: 623-639: https://doi.org/10.1080/01904160701209410

Wang, Q., Y. C. Li, and W. Klassen. 2005. "Influence of Summer Cover Crops on Conservation of Soil Water and Nutrients in a Subtropical Area." J. Soil Water Conserv. 60: $58-63$. 